\title{
Intuitive design potential for optimization of material environment
}

\author{
Jonas Jakaitis, Jonas Zukas, Vilnius Gediminas Technical University, Lithuania
}

\begin{abstract}
The exploration of a relationship between the material environment design and the society is an important research topic in achieving environmental, economic and social sustainability. The main subject of the article is the interaction between the material environment and society. Research of the material environment coherence problems is based on an innate human right to live in a cohesive environment. Aesthetic and creative criteria are important in order to understand nature - man - environment system bonds embodied in forms of the material environment. Therefore, society, material environment, and the urban spaces should be understood as an integral whole and their relations must be clarified on all possible levels to ensure human space integrity. The reflection of harmony has many forms which are related to the artistic upbringing, social life, household aesthetic, environmental sustainability, and etc.

The article is exploring contexts for the material environment optimization and the integration of an intuitive interaction principles by the method of literature review and survey. The goal of this article is to reveal the potential of the new methodical approach which may provide more opportunities for the material environment enhancement. According to the contemporary cognitive and design studies, an effective tool can be intuitive interaction forming techniques. The intuitive interaction may be optimized by integrating principles of the world's mechanical causality, human sensory and cognitive abilities. These agents can be effectively linked to convey information and to create intuitively perceived, suggestive interaction scenarios, hence, providing more universal applications to add aesthetical and functional value to the spatial expression of the material environment design.

Keywords: intuitive design, human coexistence, design criteria, social harmony, urban ecology
\end{abstract}

\section{Introduction}

Research in the urban material environment exposes aesthetic quality definition as a problem since it is a complex creative process of an architect, designer, engineer and the society. Material environment in this article is perceived as the result of anthropogenic activities [24] and in itself covers space, time, form, culture, society, economy, personal experience, etc. All these elements can be dealt with separately, but they reflect aesthetic and functional characteristics of the object as a whole [15]. Compatibility of every material object coexisting in urban space, emanating from human items and returning embodied in materials again, reveal the live process which defines coherence of the material environment [14]. This creative work has to be properly organized for us to develop functional relationships, appreciate aesthetic forms of the objects (walls of houses, street furniture, light poles, landscape elements, public art, etc.) and to create a cohesive coexistence between them and urban environment.

The purpose of this study is to explore the human ability to perceive spatial formations and interact with them on an intuitive level. The goal is to examine cultural, social and psychological contexts and their correlation with the spatial expression of the material environment on an intuitive interaction level. Interdisciplinary scientific studies would provide with the opportunity to explore the potential of intuitive interaction formation for the optimization of material environment.
When in the second half of the 19th-century modernity (based on morality, justice, and nature values recognition) raised interest in sensuous aesthetics, subjectivism and philosophic conception of existence, entire cultural and artistic spheres permeated with the ideas of rationality, efficiency, versatility and secular humanism [20]. Arts split into figurative and applied, and as a result, today, urban spaces and material environment interactions, due to the complexity and multifunctionality, are perceived as a field of applied art.

Aesthetics is defined as the science of the senses, exploring the beauty and art as fiction [1]. Methodological basis for art is formed by employing applied spheres of research, cultural tradition, and certain beauty criteria. So, the aesthetics are inherent in the process of an artistic creation and as a result creating emotional feelings, although, contemporary art can have a value by not achieving criteria of beauty. However, the authors, in accordance with the provision of art "measurement" opportunity, set by aesthetic, functional, environmental coherence and other criteria of material environmental design, defines the aesthetic term as corresponding to the requirements of beauty criteria and functional integrity [34].

Aesthetic combines a number of systemic values: beauty, pleasure, cultural and social values, history, i.e. All valuable expressions. In phenomenology term 'value' is understood as innate, it is the criterion of thinking and the cause of experience [25]. 
Cognitive doctrine is determined by a phenomenological statement about the world's spatial perception $[18 ; 16 ; 26]$, which is based on the interpretation how the field of human perception is spatially oriented: here, all items are organized according to the principle of depth. If depth is perceived as the "environment" (condition) of an object, it is easy to understand that the world is apparently constructed by means of proximity and remoteness or other systematic criteria. In this context, human comfort is usually determined by the spatial (location) causality of the material environment interactions.

Universal perception of the environment manifests throughout generalities such as a physical and mental constitution of the people, and also acquired education, experience, and cultural similarities. Human space is not objectively immutable, but more or less the same for all the people and mankind at the same time [16].

Each person is creative in one or another sphere of interest and can learn to use his creative potential in a complex and rapidly changing conditions [14]. Document for European cooperation in education and training "Education and Training 2020" highlighted an emphasis on requirements of creativity, innovation, and entrepreneurship at all educational and training levels [10]. It is clear that creative skills must be formed focusing on the consumer and creator (architect, designer) would be educated to understand and assess the specific features and criteria of the urban space material environment in a context of aesthetic, economic, and social coexistence. So, living in a culturally diverse society, it is possible to find means to share cultural resources and enjoy the diversity and high-quality of urban space material environment. The cultural and creative sectors have the capacity and are considered to be areas of growth [11].

\section{Methodology of research and materials}

Research methodology is based on a method of an interdisciplinary literature review and experimental survey. Literature review provides with the opportunity to analyze the contemporary scientific context of the intuitive interaction formation and the methodological provision to form the intuitive interaction of the material environment.

Experimental survey is allowing to create the hypothetical situations of the material environment value and its spatial organization to reveal the intuitive design potential for the optimization of material environment.

Concepts of urban space and environment are often used in various contexts of social life, as well as between planners, architects, designers, engineers or artists. Generally, the concept of environment is referring to the physical, social and domestic conditions as a whole [31]. These conditions must be taken into account in order to create secure, cozy, and attractive spaces (areas). Therefore, when describing the concept of environment, in contrast to space, an own specific set of conditions, but not the location, have to be evaluated: environment - as natural and social conditions of the whole household, urban space - as a material environment and human physical location.

So, in the particular urban spaces, the problem of harmonic coexistence emerges between environmental conditions and the factors shaping it. Creators often understand this coexistence as the cityscape. The concept of the cityscape is referring not only to the city's image, silhouette, scene, panorama sense, but also to the layout of items in the city spaces and their coexistence, as it is described by numerous researchers in their work contexts, such as: in conservation of the historical heritage [37] or humanistic idea based urban space planning [13]. The latter does not automatically create harmonious material environment coexistence because these indications are not legally regulated due to the informal and subjective factors. The perception of urban areas, in the context of shaping, is usually defined by the specific criteria: a distinctive silhouette of the city, scenic panoramas, individuality of inner spaces, or quality of the natural environment. However, a material coexistence of urban space can be perceived in another context - feeling the change of the city's trends, political, social, and economic conditions. Therefore, it does not mean that urban space can be just an aesthetic site of action and spectacle [32].

We have to evaluate urban spaces in relation of consistency and continuity in time and space as network of urban structures, surrounded by streets and paths and other anthropogenic components, such as: undeveloped urban spaces, restricting engineering and communication corridors, and natural barriers: landforms, bodies of water and green areas [5]. The lifespan of the latter is sometimes significantly greater than their surrounding material environment - the natural barriers may be periodically reconfigured, but their defined areas in the city usually remain [12]. So, they can be attributed to the city's most important structural elements that support the applied creativity.

City or region is seen as a complex, evolving spatial unit, with the local tensions, operating and exploration opportunities. In order to form sustainable urban environment strategies, it is important to identify interrelated system ecology to ensure harmonious coexistence.

Contemporary city vision and urban planning requirements acquire additional directions, such as "City without Borders", social healing, values of 
liberation and integration, a function of social education - a city as a way of life. Urban areas are intertwined with many public interests that function as structural elements of the system and its integrity is directly linked with quality or possibility of life in the city [22].

Phenomenologist Elizabeth Ströker is using the concept of Place, where human and physical space meets. This Place is significant space, where human may live not only as a body but as a soul and mind. Individual must have living environment organically coupled with its complex being, therefore through social and cultural activities a new space is created, consisting of the signifiers embodied into objects forms [36]. A new creation is often intuitively readable by the principle of comparison with physical, mathematical and cultural experiences [2].

Christian von Ehrenfels, one of the Gestalt theory pioneers, emphasized that the perceived image is not identical to the sum of elements [9] and that a person psychologically comprehends environment as a whole - sum of all perceivable things subconsciously supplemented with the missing elements. Today, this fundamental discovery of the Gestalt psychology school provides us with a special tool for the harmonization of the material environment. Gestalt principles allowing to shape practically the urban space material environment coexistence through human ability to aggregate objects of a complex material environment into certain forms [15]. The latter depends on the coexistence of existing and new artistic ideas, the artist's moral attitude, and skills to convey a thought. Harmony and completeness of urban space and material environment, become a consolidating factor in society, often the cause of pride of its own environment [21].

According to the author's research [23], ninetenths of the respondents say that the clarity of urban space, the shape of objects and their mutual coexistence are the most important psychophysiological comfort determining criteria of urban space. Therefore, material environment coexistence planning process, should not only analyze impact of particular shapes, structures or materials to each other and understand operation patterns of each structure, but also to complement human coexistence quality by bringing the world of human harmony emanating from things out and embody it into new things again, returning to the same man as a material environment.

Urban planning, design, and art create dynamic systems that question and complement each other. As an example in today's cultural context, public art survival problems became particularly acute, especially as evidenced in the post-Soviet countries, never the less similar phenomena can be observed in other post-authoritarian societies when particular public art aesthetics were developed to strengthen ideological model [6]. Clearly, this can be seen in the context of Lithuania, when urban space art crisis appeared in the first years of restored independence. The change of the political system and social values have changed art appreciation, when ideological content became irrelevant or even offensive in today's cultural environment. The perceived crisis of values, manifesting as an opposition to changes, often was accompanied by the older generation's lifestyle or habits, as a result, creating difficulties for social cohesion [27].

To ensure material environment coexistence effectiveness, decisions must be clarified on all levels of interaction, including sensory, cultural and demographic context, as well as region's development vision that meets the needs of the population.

Identification of intuitive interaction research problematics in design and psychology, reveal possibilities to explore human cognition and environment interaction, developing more intuitive (less knowledge demanding) and as a result, more culturally and socially universal communication means [17].

Term Intuition in classical understanding means "insight, direct or immediate cognition, spiritual perception", originally theological, from Late Latin Intuitionem (nominative intuitio) "a looking at, consideration" [28]. The issue of intuition studies rests on the aspects of the cognitive architecture, sensory abilities, psychology and cultural links [8]. A human perceives the world via his senses and classifies the following data into the environment context (including cultural). "The better material environment structure/function linked with the user senses the more natural - more intuitive relationship with it" [19].

Modern cognitive sciences implying that human cognition framework is based on the thermodynamic principles $[2 ; 14 ; 33 ; 35]$, therefore intuitive interaction may be optimized by employing human and environment mechanical interaction specifics, such as energy saving psychophysiological aspects, shape physical expression, sensory and anthropometric data. These elements can be effectively organized, creating a suggestive, intuitively readable, seamless interaction scenarios [3]. On this basis a conception for the material environment intuitive interaction optimization is proposed.

\section{Discussions and results}

Perceived expression elements of the physical shape are very diverse and their interrelation states (proximity, separation, center, joint, closure, balance, etc.). These material environment participants obtain values in a particular physical, 

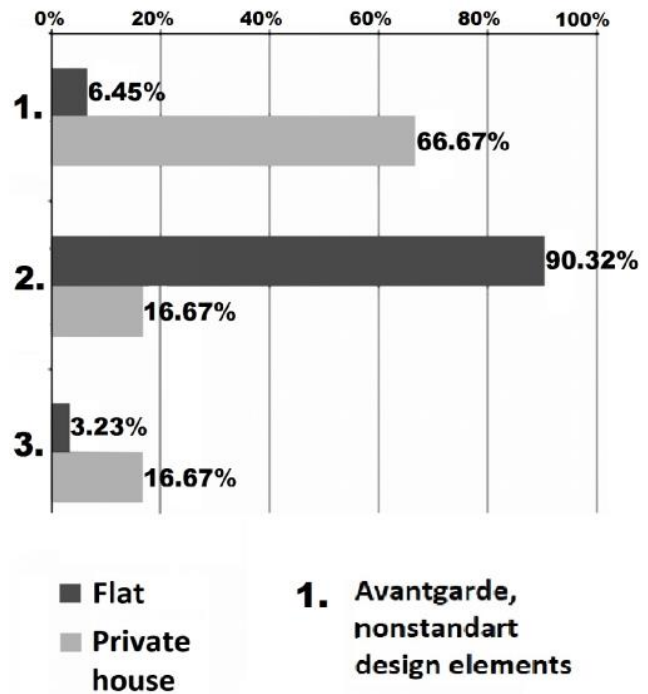

\section{Few functional, practical, good quality elements}

3. Longstanding, time-tested elements

Fig. 1. What is more important in your neighborhood material environment quality?

Created by the authors, 2018.

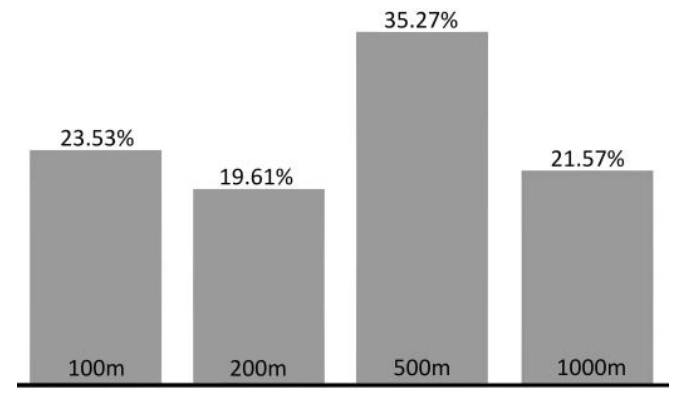

Fig. 2. What is the minimum distance from your home you would prefer national significance monument (in meters)? Created by the authors, 2018.

cultural, or social environment context $[7 ; 4]$. These values may be encoded on many levels, hence invoking intuitive communication methods by integrating mechanical causality principles to the aesthetical and functional content of the material environment, would provide more applicability for the particular function and user [14]. This approach would allow developing innovative techniques for the optimization of the material environment design.

In March of 2017, the authors conducted a survey on behalf of Vilnius Gediminas Technical University, where Vilnius city residents were asked to assess particular object's proximity (one of five key principles of perceptual organization for interaction design derived from Gestalt theory [29] which could also be perceived as an object mechanical arrangement condition) from their home environment in an attempt to establish personal, social and cultural priorities. According to the survey, the majority of the responded Vilnius city house owners clearly have a more positive attitude towards experimental design solutions near their residence area (Fig. 1). This might be attributed to the stronger sense of personalism, the perception of their home space extent, more allied communal relations, and self-confidence in forming material environment quality. However, the apartment owners tend to choose more practical, functional and good quality objects and this might be attributed to the social factors as well. When the public interest is represented by many different opinions there are fewer possibilities for agreement among them. Presumably avoiding conflict of subjective (taste) factors and focusing on material and functional quality gives more reliable value judgement.

When respondents were asked regarding the distance from their home of the national significance monument, the majority gave priority for the greater distance (Fig. 2).

As a result, it can be assumed, that the social weight of such an object would intervene with the personal home space/environment.

There is a correlation with a spatial type of the area people living in, housing, their demographics and the preference of the material environment design. Therefore, it could be beneficial to integrate intuitive aspects of material environment spatial design to form more cohesive environment on various levels - personal, social, and economical.

Definitely, there are regional cultural and social identity specifics but it is possible to optimize material environment coexistence by integrating district/local demographic and general preferences survey data, and employing appropriate design techniques to improve its aesthetical and functional qualities. There is an opportunity to establish effective communication when in a dialogue members of university research teams, city municipality, and community act on their own level of competence [30]. On the other hand, there is a possibility to enhance the material environment design of a specific demographic area by applying generalized conditions even if the residents of the area are socially passive.

\section{Conclusions}

Urban areas, especially public ones, have no other intended purpose besides to ensure human communication, social, cultural needs and fulfill safety objectives. Therefore, in a context of these criteria, quality of the surrounding material environment (aspirational and psychophysiological conditions) of urban areas is essential to human coexistence. A human is receptive to urban area's size, shape, color, function and the sum of objects as a whole. A material environment is often close and 
well known, thus its cultural, social and economic coexistence is understood as an expression of the identity.

Interdisciplinary studies and their comparative analysis allow to identify principles for integration and optimization of an intuitive interaction. It can be implemented by exploring the environment and human spatial interaction specifics, revealing the creative and methodical possibility to relate environmental mechanical causality with the human cognitive abilities to enhance the functional and aesthetical design of the material environment. This researched and integrated methodic would create opportunities for the innovative material environment design.

Methodology for the integration of the intuitive interaction principles into the material environment elements should investigate specifics in terms of contemporary cultural, social, psychological and physical contexts. These contexts would provide value conditions for the material environment functional and aesthetical qualities to optimize personal, cultural and social communication.

\section{References}

1. Aesthetics [online]. Internet Encyclopedia of Philosophy [cited 12.03.2017]. http://www.iep.utm.edu/aestheti/

2. Battaglia, P. W., Hamrick J. B., Tenenbaum J. B. Simulation as an engine of physical scene understanding. Proceedings of the National Academy of Sciences, Vol. 110 (45), 2013, p. 18327-18332.

3. Blackler, A. L., Popovic V., Mahar D. P. Intuitive use of products. Design Research Society International Conference, London, September 5-7. London: Staffordshire University Press, 2002, p. 120-134.

4. Bloch, P. H. Seeking the ideal form: Product design and consumer response. The Journal of Marketing, 1995, Vol. 59 (3), p. 16-29.

5. Buivydas, R. Viešųų erdvių transformacija Lietuvos miestuose (Transformation of Urban Spaces in Lithuanian Cities). LOGOS, 2011, Vol. 66, p. 132-141 (in Lithuanian).

6. Citvarienė, D. The ideological changes of Lithuanian art discourse in the 1990s. Doctoral dissertation. Vytautas Magnus University, 2008

7. Crilly, N., Moultrie, J., Clarkson, P.J. Seeing things: consumer response to the visual domain in product design. Design Studies, 2004, Vol. 25 (6), p. 547-577.

8. Dijksterhuis, A. Think different: The merits of unconscious thought in preference development and decisionmaking. Journal of Personality and Social Psychology, 2004, Vol. 87 (5), p. 586-598. DOI:10.1037/00223514.87.5.586

9. Ehrenfels, C. V. On Gestalt-qualities. Psychological Review, 1937, Vol. 44 (6), p. 521-524.

10. Education and Training 2020 [online]. European Commission, 2009 [online 25.04.2017]. http://ec.europa.eu/education/policy/strategic-framework_en

11. Thomson, M., Koskinen, T. Design for growth and prosperity. Report and Recommendations of the European Design Leadership Board, DG Enterprise and Industry of the European Commission, 2012.

12. Frick, D. Spatial Synergy and Supportiveness in Public Space. Journal of Urban Design, 2007, Vol. 12 (2), p. 261274. doi.org/10.1080/13574800701306369

13. Gehl, J. Life Between Buildings: Using Public Space. Translated by Jo Koch. New York: Van Nostrand. Reinhold, 1987.

14. Gerstenberg, T., Tenenbaum, J. Intuitive Theories. In: The Oxford Handbook of Causal Reasoning. Waldmann M. R. (ed.). New York, NY: Oxford University Press, 2017, p. 515-548.

15. Guberman, S. On Gestalt theory principles. Gestalt Theory, 2015, Vol. 37 (1), p. 25-44.

16. Heidegger, M. Being and Time. State University of New York press, 1953. 50p.

17. Humphries, T. Considering Intuition in the Context of Design, and of Psychology. Cardiff School of Art and Design, Cardiff Metropolitan University, Wales, 2012. [online 22.10.2017]. http://theohumphries.com/papers/HUMPHRIES_intuition_psychology_design.pdf

18. Husserl, E. Logical Investigations. Translated by Findlay J. N. London: Routledge, 1973.

19. Hodgkinson, G. P., Langan-Fox, J., Sadler-Smith, E. Intuition: A fundamental bridging construct in the behavioural sciences. British Journal of Psychology, 2008, Vol. 99 (1), p. 1-27.

20. Younesu, S. Ilgaamžiai miestai, tvarūs statiniai ir ideologiniai jų priešai. Kulturos barai, 2014, Vol. 9, p. 8-12 (in Lithuanian).

21. Jabareen, Y. R. Sustainable urban forms: Their typologies, models, and concepts. Journal of planning education and research, 2006, Vol. 26 (1), p. 38-52.

22. Jacobs, J. The Death and Life of Great American Cities. New York: Vintage Books, 1961, p. 261-267.

23. Jakaitis, J. Miesto erdvinio formavimo dalyviu diskursas šiuolaikinès demokratijos sąlygomis: monografija. Vilnius: Technika, 2013 (in Lithuanian).

24. Jakaitis, J., Raudeliuniene, J. Research on the urban material environment design: creativity aspects. 2nd International Multidisciplinary Scientific Conference on Social Sciences and Arts SGEM 2015, 2015, Book 4, Vol. 1, p. 573-580.

25. Kelly, E. The Phenomenology of Value. In: Material Ethics of Value: Max Scheler and Nicolai Hartmann. London, New York: Springer Science \& Business Media, 2011, 79 p.

26. Merleau-Ponty, M. Phenomenology of perception. London, New York: Routledge, 2012. 696 p

27. Mole, R. The Baltic States from the Soviet Union to the European Union: Identity, Discourse and Power in the PostCommunist Transition of Estonia, Latvia and Lithuania. London, New York: Routledge, 2012, p. 167. 
28. Intuition [online]. Online Etymology Dictionary [cited 20.04.2017] http://www.etymonline.com/ index.php?term=intuition

29. Paay, J., Kjeldskov, J. Understanding the user experience of location-based services: five principles of perceptual organisation applied. Journal of Location Based Services, 2008, Vol. 2(4), p.267-286. DOI $=10.1080 / 17489720802609328$

30. Pearson, J., Robbins, M. (eds.). University - Community Design Partnerships Innovations in Practice. New York: Princeton Architectural Press, 2002. 96 p.

31. Rapoport, A. The Meaning of the Built Environment: A Nonverbal Communication Approach. Tucson: University of Arizona Press, 1982, p. 107.

32. Samalavičius, A. Miestas ir protas: urbanistinès teorinès refleksijos XX a. Vakaruose: monografija. Vilnius: Technika, 2013 (in Lithuanian).

33. Smith, K. A., Battaglia, P., Vul, E. Consistent Physics Underlying Ballistic Motion Prediction. In Proceedings of the 35th Annual Meeting of the Cognitive Science Society, 2013, Vol. 35 (35), p. 3426-3421.

34. Aesthetic Judgment [online]. Stanford Encyclopedia of Philosophy. [cited 06.10.2017]. https://plato.stanford.edu/ entries/aesthetic-judgment/

35. Stephens, G. J., Mora, T., Tkačik, G., Bialek, W. Statistical thermodynamics of natural images. Physical Review Letters, 2013, Vol. 110 (1), p. 018701. DOI:10.1103/PhysRevLett.110.018701

36. Ströker, E. Investigations in Philosophy of Space. Athens, Ohio: Ohio University Press, 1987. 321 p.

37. Tung, A. M. Preserving the World's Great Cities: The Destruction and Renewal of the Historic Metropolis. New York: Clarkson Potter, 2001. 469 p.

INFORMATION ABOUT THE AUTHORS:

Jonas Jakaitis - Dr. Prof. of the Design department, Vilnius Gediminas Technical University; Pylimo g. 26 / Traku g. 1, LT-01132 Vilnius, Lithuania; phone: +370 64092987; e-mail: jonas.jakaitis@ @gtu.lt

Fields of interest: industrial design in urban space, landscape architecture, urban planning and design, public and private partnership, society participation in urban design and sustainable formation of living environment.

Jonas Zukas - PhD student, Lecturer of Design department, Vilnius Gediminas Technical University; Pylimo g. 26 / Traku g. 1, LT-01132 Vilnius, Lithuania; phone:+37060693385; e-mail: jonas.zukas@vgtu.lt Fields of interest: principles of the intuitive design, spatial aesthetics, industrial design and sculpture.

Kopsavilkums. Sasaistes pētīšana starp materiālās vides dizainu un sabiedrību ir nozīmīga pētījuma tēma, lai panāktu vides, ekonomikas un sabiedrības ilgtspējību. Galvenais pētījuma objekts ir mijiedarbība starp materiālo vidi un sabiedrību. Pētījums par materiālās vides saskaņotības problēmām balstās iedzimtajās cilvēku tiesībās dzīvot vienotā vidē.

Estêtiskie un radošie kritēriji ir svarīgi, lai saprastu sistēmas daba-cilvēks-vide sasaistes, kas ir ietvertas formās un materiālajā vidē. Tādē l sabiedrība, materiālā vide, un pilsētvide ir jāsaprot kā ietverošs veselums.

Raksts atspoguḷo konteksta meklējumus materiālās vides uzlabošanai un intuitīvu iesaistî̌šanās principu integrēšanu. Pētījums veikts, izmantojot literatūras apskatu metodi un aptauju. Raksta mērkis ir atklāt jaunas metodiskās pieejas potenciālu, kas varētu sniegt vairāk iespēju materiālās vides uzlabošanai. Saskaṇā ar mūsdienu izziṇas un dizaina pētījumiem, efektīvs veids var būt intuitīvās iesaistes veidošanas tehnika. 